\title{
New Pathways to Learning: The Team Teaching Approach. A Library and Information Science Case Study
}

\author{
Helen Partridge and Gillian Hallam \\ Queensland University of Technology, Brisbane, Australia
}

\author{
h.partridge@qut.edu.au g.hallam@qut.edu.au
}

\begin{abstract}
The Queensland University of Technology (QUT) challenges its teachers to provide innovative and dynamic learning environments that foster excellence in student learning. This paper discusses how the Faculty of Information Technology is using collaborative teaching and learning strategies to meet this challenge. The paper explores how team teaching and learning is being implemented within the Graduate Diploma in Library and Information Studies. The core unit ITN336 Information Resources is used as a case study. The paper discusses the practical implications of incorporating team teaching into a unit's curriculum and how it impacts on the teaching and learning process. Student attitudes towards team teaching are explored. The paper concludes by discussing how team teaching is not just a technique that can be applied to divide the labour within a unit, rather it is a creative and thoughtful mechanism for fostering a dynamic studentcentred learning environment.
\end{abstract}

Keywords: team teaching, library and information science, IT education, student attitudes.

\section{Introduction}

Universities in Australia, and throughout the world, have begun to explore team teaching as a means of promoting student learning outcomes. Whilst in recent years some examples of university level teaching have emerged in the literature (Bakken, Clark \& Thompson, 1998; Letterman \& Dugan, 2004; Vogler \& Long, 2003), for many university teachers team teaching remains unexplored territory. Speer and Ryan (1998) suggest that team teaching "offers a promise of change to those who desire transformation in their teaching lives" (p. 48). They challenge university teachers to take the risk and "[share] their class room with another" (p. 48). The Queensland University of Technology (QUT) is committed to providing "one of the best learning environments in Australia" (QUT, 2003, p. ii). To this end QUT encourages its academic staff to "develop and evaluate innovative and experimental teaching programs" (QUT, 2004a, p. 4).

Taking on board the challenges posed by Speer and Ryan and QUT, the current paper will outline and critically discuss the application of team teaching to foster student learning within the Faculty of Information Technology at QUT.

Material published as part of this journal, either on-line or in print, is copyrighted by Informing Science. Permission to make digital or paper copy of part or all of these works for personal or classroom use is granted without fee provided that the copies are not made or distributed for profit or commercial advantage AND that copies 1) bear this notice in full and 2) give the full citation on the first page. It is permissible to abstract these works so long as credit is given. To copy in all other cases or to republish or to post on a server or to redistribute to lists requires specific permission from the publisher at Publisher@InformingScience.org
More specifically, after considering the difficulties of establishing a clear definition of team teaching within the higher education context, the paper will discuss how the implementation of collaborative teaching within the Graduate Diploma in Library and Information Studies articulates the au- 
thors' understandings of socially constructed knowledge. The paper will outline the team teaching and learning model used within the core unit ITN336 Information Sources. The preliminary findings on student perceptions and experience of team teaching will be discussed.

\section{Team Teaching}

\section{Attempts at a Definition}

In 1995 Davis suggested that team teaching was not easily defined. He suggests that it refers "most often to the teaching done in interdisciplinary course by the several faculty members who have joined together to produce that course" (pg. 6). Davis highlights the difficulty of determining what actually "constitutes the 'team' part of team teaching" (pg. 6) and proposes that teaching teams function along a continuum. At one end of the continuum there are "courses planned by a group of faculty and then carried out in serial segments by the individual members of the group" (pg. 7). At the other end of the continuum sit the "courses both planned and delivered by a group of faculty working together closely as a team" (pg. 7). McDaniel and Colarulli (1997) use the term "team coordinated teaching" to describe the interdisciplinary delivery of courses, while the term "team teaching" refers to the more collaborative, interactive process of teaching. The continuum is presented as four dimensions of collaboration that impact directly on student learning: the degree of integration of ideas and perspectives within the curriculum; the degree of interaction between academic staff and students in the teaching and learning process; the degree of active learning and student engagement in the learning process; and the degree of faculty autonomy or independence in the teaching and learning process.

Watkins and Caffarella (1999) present four models of team teaching that are based on variations in working style: parallel teaching, serial teaching, co-teaching and co-facilitation. Eisen and Tisdell (2000) contend that the definition offered by Davis (1995) and the models offered by McDaniel and Colarulli (1997) and Watkins and Caffarella (1999) focus too strongly on teacher control which can blur the essential relationship between teaching and learning. They stress that "teaching and learning are inextricably connected and that a key strength of the teaming process is that it generally serves to solidify this connection" (pg. 6). It is suggested that "teaming can improve the delivery of teacher-centered education... and can... create practices and environments that are fully inclusive of learners" (Eisen \& Tisdell, 2000, pg. 6). In this environment, the teachers are no longer viewed as disseminators of knowledge, but as collaborative learners themselves. In addition, Eisen and Tisdell (2000) argue that the current definitions imply that team teaching and learning occurs only in formal settings. In contradiction to this, they declare that team teaching "often occurs in communities or workplaces that are not bounded by four walls or institutional structures" (pg. 7).

Unfortunately, in their discussions on team teaching and learning situations, Eisen and Tisdell do not offer an alternative definition of team teaching. However, based on the above discussion the following observations can be made about team teaching: (i) it involves two or more teachers within the teaching and learning environment; (ii) it can vary along a continuum of collaboration; (iii) it facilitates a learning community by impacting on both teaching and learning; and (iv) it can be both formal and informal. The current paper will present a case study exploring these dimensions of team teaching within the context of IT education.

\section{Team Teaching in Higher Education: A Brief Literature Review}

Team teaching is becoming more and more a topic of conversation within the higher education sector, a brief review of the key writings in this emerging area will follow. The current literature suggests that the vast majority of university teachers who are engaged in team teaching find the 
experience challenging, enjoyable and worthwhile. For example, in $1992 \mathrm{McKee}$ noted the following about his experience in team teaching a social studies course to undergraduate students: "the experience provides me with tremendous professional growth. Having the opportunity to plan, teach and evaluate the class with another experienced professional really heightens the pleasure of teaching" (McKee \& Day, 1992, pg. 184). More recently Bradshaw and Hinton (2002) described their use of team teaching in a first year communication course as a "useful medium to create a sense of fun, facilitate an environment conducive to academic discourse and scholarly enquiry" (para. 22). The process of team teaching can therefore be viewed as a "mode for developing [teachers] as more critically reflective learners" (Eisen \&Tisdell, 2002, para. 10).

Over the years several benefits for teachers involved in team teaching have been identified. Firstly, team teaching helps each teacher to keep in check their "ingrained tendency to slip back into the banking mode of teaching with the student as passive receptacle" (Robinson \& Schaible, 1995, para. 20). Secondly, team teaching can help overcome the "frequent sense of isolation felt by many faculty members" (Robinson \& Schaible, 1995, para. 22). Finally, team teaching can engage teaching staff in more "philosophical discussions than the usual discourse over class materials" (Letterman \& Dugan, 2004, p 77).

For the student, team teaching offers an equally diverse array of benefits. In 1998 Hinton and Downing received positive feedback from students enrolled in a team taught class with ninetyfour percent of the students expressing a preference for team teaching over the traditional teaching method. Hinton and Downing suggested that team taught classes are more beneficial to students because they are fundamentally more interesting and challenging. Recent studies suggest that team teaching benefits the student by providing a great opportunity for individualized help (McKee \& Day, 1992) and the chance to experience multiple perspectives from the 'team' of teachers on the content and issues being discussed (Hinton \& Downing, 1998; McKee \& Day, 1992; Robinson \& Schaible, 1995). Letterman and Dugan (2004) also suggest that team teaching can help promote diversity by including team members with different ethnic, racial and cultural background. The focus on transferable skills as desirable graduate outcomes has led many universities to embed the development of generic capabilities in the curriculum, with emphasis placed on the students' development of teamwork skills through group and project work. The teaching team can serve as a model for interaction between the different team members: "If we preach collaboration but practice in isolation... students get a confused message. Through learning to 'walk the talk', we can reap the double advantage of improving our teaching as well as students' learning” (Robinson \& Schaible, 1995, para. 26).

Nevertheless, some students find themselves challenged by the team process. If they are used to the traditional didactic model of the lecture to transmit knowledge, they may "find it unsettling to be confronted with alternative interpretations" (McDaniel \& Colarulli, 1997, pg. 34) and "struggle with the ambiguity of faculty conversations when no 'right answer' or one truth is communicated which they can write in their notes" (pg. 34). They feel the teachers are at fault for generating uncertainty and insecurity.

Team teaching, however, is not without its difficulties or problems for staff. For many academic staff, it is seen as time consuming and difficult to organize (Davis, 1995). Conflict can arise if there is uncertainty or disagreement in the role of each team member (Letterman \& Dugan, 2004). There may be concerns about the loss of autonomy: individual teachers may fear that the collaborative process, which involves "a curricular theme, common assignments and readings, shared presentations, and shared expectations and grading systems for student work" (McDaniel \& Colarulli, 1997, pg. 28), will result in the sense of losing control over their own teaching practice. For many, the risks are high: "exposing themselves and their teaching to their colleagues and engaging in experimentation" (McDaniel \& Colarulli, 1997, pg. 28) pushes them out of their traditional comfort zone. Linked to this last point is the issue of academic ego. George and Davis-Wiley 
(2000) cite this last point as one of the main reasons that team teaching has not become more prevalent in higher education.

There is also the question of teaching loads and administrative support from the university (George \& Davis-Wiley, 2000), often seen as the need to attain a balance between costs and productivity (McDaniel \& Colarulli, 1997), specifically when the higher education sector as a whole is facing increasing scrutiny from political and economic perspectives: "In the short run, some institutions simply do not have sufficient income, given demands on that income, to reduce class size and hire additional faculty; financial survival in the short term drives the decision making. To achieve collaboration by having more than one teacher in a classroom is typically very expensive and negatively influences short term productivity, however desirable it might be in terms of learning outcomes or longer-term productivity" (McDaniel \& Colarulli, 1997, pgs. 28-29).

There is much discussion in the literature and many initiatives in the universities to introduce technology as a tool for cost reduction within the faculty, especially in the context of IT education. It is important that a distinction is made between technology as a mode of learning and technology as a tool to support learning. The learning theories of constructivism argue that new knowledge is created as "learners construct their own reality or at least interpret it based on their perceptions of experiences, so an individual's knowledge is a function of one's prior experiences, mental structures and beliefs that are used to interpret objects and events" (Jonassen, 1991). The social dimension of knowledge construction requires students to interact with peers and teachers in a collaborative and social context. While technology can be used to support collaborative learning through, for example, online discussion forums or chat rooms, it is argued that team teaching in the face-to-face learning environment, with interaction between students and staff, has significant value as a "'low tech' alternative for facilitating this kind of learning that develops skills in critical thinking and new knowledge construction" (Eisen \& Tisdell, 2002, para. 1).

While the administrators demand cost reductions and productivity increases, they are also calling for demonstrable evidence of the value of the educational product - quality of learning and teaching and student learning outcomes. The ability to maximise learning is particularly relevant to postgraduate students, especially in fee-based professional courses such as library and information management programs. The majority of students regard the cost of their education as a significant investment in their future careers, so that the learning experience is an important aspect of their purchasing behaviour. McDaniel \& Colarulli (1997) strongly believe that "collaborative models of teaching and learning will be increasingly adopted because they have the potential to improve learning outcomes" (pg. 30). The challenge therefore is to "balance the values of faculty collaboration and all the benefits it brings to students with the realities of administering and budgeting academic programs" (McDaniel \& Coarulli, 1997, pg. 30).

Increasingly, universities highlight the importance of providing “outstanding learning environments and programs which lead to excellent outcomes for graduates, enabling them to work in, and guide a world characterised by increasing change" (QUT, 2004b, para. 1). At QUT, the value of scholarly learning and teaching practices has been emphasised with the dissemination of the QUT Teaching Capabilities Framework: delivering outstanding student learning through excellence in teaching. QUT offers guidelines for teaching practices that can successfully stimulate interaction and dialogue, and reciprocity and cooperation, between students and staff, and that encourage deep learning by supporting diverse learning styles and regarding the learning process as a social responsibility for all individuals for life. Team teaching provides the opportunity to develop a more innovative and cooperative learning environment.

For those academics wishing to pursue the team teaching approach Bennet, Ishler and O'Loughlin (1992) provide the following principles for success: 
- Collaboration can only be effective when there is a genuinely equal relationship among all parties;

- Differing knowledge bases, such as theatrical knowledge and practical knowledge, must be of equal importance

- Both parties must commit to engaging in online dialogue and mutual inquiry

- All participants must have opportunities to experience each other's reality in mutually supportive environment

- Collaborators must be able to discuss openly any issues or problems that arise.

Reflecting on their own team teaching experiences with graduate students, George and DavisWiley (2000) have more recently offered the following twelve guidelines for successful practice in teaching collaboratively:

- Before doing team teaching agree on basic expectations or each teacher.

- Team teaching takes much extra time for planning and evaluation. It is crucial to provide time for the collaborators to discuss and reflect together.

- Decide whether or not interruptions during one members' presentation of material are acceptable to the other.

- Make all evaluation criteria clear to the students. Assure them that both teachers will follow the same evaluation criteria for grading.

- At all times, be consistent with your instructional team member and with the students.

- Leave your ego at the door! You are an equal member of an instructional team

- Be prepared to work hard.

- Learn from your team-teaching experience and from your team teaching colleague

- Be willing to admit that you can be wrong at times.

- Never, never upstage your colleague in the classroom.

- Remember you are a team.

- Enjoy the experience, learn and grow from it.

These principles have guided the collaborative practices of one successful teaching team at QUT.

\section{The Case Study}

\section{The Graduate Diploma in Library and Information Studies}

The Graduate Diploma in Library and Information Studies (GDLIS) is a course offered via the School of Information Systems within the Faculty of Information Technology. It consists of seven core academic units and one elective unit. The course is completed in one year full-time or two years part-time. The GDLIS is aimed at providing students with the theoretical and practical skills needed to identify, select, assemble and disseminate information resources to meet the information needs of others. On completion of the course students are eligible for professional membership of the Australian Library and Information Association (ALIA). In 2004 there were 83 students enrolled in the course, 34 full-time and 49 part-time.

While the GDLIS is an example of a tertiary education course that aims to prepare graduates for employment, the academic staff are mindful of the enormous range of employment opportunities available to 'information professionals'. The landscape is extensive, from the broad levels of academic libraries, public libraries, State and National libraries, through to the narrower levels of 
special libraries and information centres, such as law libraries, health and medical centres, music libraries etc. Opportunities also exist beyond this more traditional library context, with career avenues available within knowledge management, records management, Internet and intranet development and so on.

\section{ITN336 Information Sources}

ITN336 Information Sources is a core unit undertaken during semester 1 of the GDLIS. The unit introduces students to the field of reference work in libraries and information centres. The curriculum aims to cover information retrieval techniques, the role of the reference and information service in libraries, the development of digital reference services and the impact of technology of reference collections and services. The unit also focuses on helping students to develop core generic capabilities including project management, oral and written communication and team work skills. In Semester 12004 there were 52 (33 female and 19 male) students enrolled in the unit, 34 full time and 18 part time.

In discussing their experience of team teaching an undergraduate teacher education course Bakken, Clark and Thompson (1998) observed that the strongest asset to the success of the teaching team was the "personalities and life experiences each member brought to the team" (pg. 157). The teaching team for ITN336 consisted of two full time teachers: Gillian Hallam and Helen Partridge. Both commenced work at QUT in early 2001. Their industry experiences are diverse with Gillian having worked as a librarian in the corporate and government sectors in Australia and South Africa, and Helen as a librarian in the public and special library contexts in Australia and the United Kingdom. Importantly, both staff share a common philosophy of learning and teaching: the desire to create a student-centred environment that is conducive to learning; to encourage self-sufficient learners; to be fair in all their actions; to embrace change and to constantly strive for continuous improvement; and to have fun so that both students and teachers enjoy the learning experience.

\section{The Rationale for Team Teaching in ITN336}

Team teaching has been used in the unit ITN336 from 2001 to 2004. A collaborative approach has been applied to teaching and learning within the unit for three fundamental reasons:

1. The students enrolled in the unit are not a homogeneous group. The students represent a wide diversity of characteristics including gender, personal interests, employment history, academic background and life experiences. Such diversity has significant implications for the creation of an inclusive and successful teaching and learning environment. As each student is at a different stage in their personal and professional lives, they will all have their own understanding of the immediate academic context and will have disparate perceptions and experiences in terms of the learning process. Team teaching was identified as a core strategy that could be used to accommodate such diversity. Team teaching would essentially value the differences in student personality and backgrounds and help all students maximize their learning opportunities.

2. The library and information profession is constantly changing; with the Information Sources subfield in particular undergoing radical changes and developments as a consequence of new and emerging trends within the many and varied contexts of the profession (eg. public library, corporate sector, academic library etc). A team teaching approach in the unit would help avoid the stagnation that could potentially occur with a single lecturer teaching into the program, so that the professional discussions between the teaching staff would ensure that the curriculum remained current and cutting edge across all sectors. 
3. The well-rounded library and information professional of the twenty-first century needs to be not only discipline savvy but also skilled in the area of generic capabilities. Modern day library education therefore must develop a curriculum that encompasses both discipline knowledge and work place skills. Three generic capabilities were identified as relevant to the current unit: oral and written communication, team work and project management. The unit curriculum was designed to incorporate opportunities for students to develop their skills in these generic capabilities along side the discipline knowledge. Team teaching offers the opportunity for students to learn from the teaching staff as they model the generic capabilities being explored. Team teaching is makes a particularly relevant contribution to the students' understanding of team processes.

\section{Embedding Team Teaching into ITN336}

In discussing their experience of team teaching an interdisciplinary honours course Letterman and Dugan (2004) concluded that "team teaching is an innovation that can foster student enthusiasm and learning" (pg. 79) but to be successful it is essential to "think through the team-taught course process from start to finish, allowing ample time to prepare" (pg. 79). They recommend to "meet regularly and talk candidly...plan your course, identify any potential complications, and formulate your response for anticipated problems, and you will spend more time enjoying your team teaching experience and less time searching for solutions" (pg. 79).

The planning for ITN336 in 2004 began with a meeting prior to the beginning of semester. The meeting was used to critically review the student feedback and comments received at the end of the previous year's course offering and to identify any curriculum refinements or changes needed

\section{Queensland University of Technology \\ School of Information Systems}

ITN336 Information Sources

Semester 1,2004

\begin{tabular}{|c|c|c|c|}
\hline Week & Session & Chair (Lead Instructor) & Day \& Time \\
\hline 1 & Unit Introduction & Gillian \& Helen & Wed $3^{\text {rd }}$ March 6-7pm \\
\hline 2 & $\begin{array}{l}\text { Workshop: Reference \& Information Work - } \\
\text { The Big Picture }\end{array}$ & Gillian & Wed $10^{\text {th }}$ March 6-9pm \\
\hline 3 & $\begin{array}{l}\text { Workshop: Searching for Information Online \& } \\
\text { Writing a Literature Review Part I }\end{array}$ & Helen & Wed $17^{\text {th }}$ March 5-9pm \\
\hline \multirow[t]{2}{*}{4} & $\begin{array}{l}\text { Workshop: Searching for Information Online \& } \\
\text { Writing a Literature Review Part II }\end{array}$ & Helen & Wed 24 $4^{\text {th }}$ March \\
\hline & $\begin{array}{l}\text { Workshop: Workplace Skills for Library and } \\
\text { Information Professionals }\end{array}$ & Gillian \& Helen & Sat $27^{\text {th }}$ March 9-4 pm \\
\hline 5 & Workshop: Research Methods \& Libraries & Helen & Wed $31^{\text {s1 }}$ March 5-9pm \\
\hline 6 & No Classes & & \\
\hline 7 & $\begin{array}{l}\text { Student Presentations } \\
\text { Students are to give a 10-minute presentation } \\
\text { discussing work completed so far. }\end{array}$ & $\begin{array}{l}\text { Students are asked to attend at least } 1 \text { hour of } \\
\text { presentations. }\end{array}$ & Wed 21 $1^{\text {st }}$ April 6-9pm \\
\hline 8 & Team Feedback & $\begin{array}{l}\text { Students groups will meet with Gill and Helen } \\
\text { to discuss progress to date. }\end{array}$ & Dates to be Advised \\
\hline 9 & Workshop: Reflecting on Reference Part I & Gillian & Wed $5^{\text {th }}$ May 5-9pm \\
\hline 10 & Workshop: Reflecting on Reference Part II & Gillian & Wed $12^{\text {th }}$ May $5-9 \mathrm{pm}$ \\
\hline 11 & Poster Conference & $\begin{array}{l}\text { Students will present their posters via a poster } \\
\text { exhibition. }\end{array}$ & Wed $19^{\text {th }}$ May 6-8pm \\
\hline 12 & No Classes & & \\
\hline 13 & No Classes & & \\
\hline
\end{tabular}

Figure 1: The ITN336 Schedule Semester 12004 
for the new semester. The meeting also provided the opportunity for the teaching team to discuss their concerns and aspirations for the future directions of the unit and to agree upon both the learning objectives and the teaching and learning approaches that would underpin the unit. A teaching and learning schedule for the semester was established (see Figure 1).

The schedule was developed to use the "strengths, insights and experiences... [of each team member]... to create lessons and activities that not only define and develop important points and ideas but also maintain a high level of student interest" (Vogler \& Long, 2003, pg. 123). In 2004 the teaching team undertook one significant change to the design and delivery of the unit. Instead of the traditional 1 hour lecture and 2 hour tutorial format a series of four hour workshops were introduced into the unit. The rationale for a workshop format was: (i) to more effectively cater to the students learning needs by taking into consideration their workloads in ITN336 and the other units they were enrolled in (i.e. the workshops were scheduled at times throughout the semester to avoid times when students would be preoccupied with completing assignments or sitting exams); and, (ii) to encourage students to think of themselves as new professionals in the field (i.e. the workshops were designed and delivered in replication of a Continuing Professional Development Program). One member of the teaching team was designated the role of Lead or Primary Instructor for each workshop. The Lead Instructor was responsible for coordinating the development and design of the workshop. It is important to note, however, that the planning and design of each workshop did not take place in isolation. The teaching team discussed the broad concepts to be explored in each workshop; it was then left to the Lead Instructor to bring the discussions to life via a carefully constructed workshop. Both members of the teaching team attend all class sessions. Whilst the Lead Instructor may be viewed as the "primary teacher" for each session (i.e. doing most of the talking, co-ordination of class room activities etc) the other member of the teaching team provides teaching support (i.e. liaising with students as they work on group activities, handing out class materials etc) and actively participates in the class room discussions.

Luca, Oliver, Omari \& Dubar propose that "assessment is instrumental to the whole curriculum design process"(2001, 11-1). Assessment was therefore a key consideration during the initial planning stage by teaching team. Bowden and Marton (1998) also believe that "an integrative approach to assessment" (p.162) can drive the teaching and learning process, with clear articulation of teaching and learning objectives. The correlation between assessment and student learning outcomes is therefore critical. Ramsden (1992) discusses the importance of "more developed models of assessment" (pg. 186). Simple models of assessment can be regarded "as an addition to teaching, rather than an essential part of it" (pg. 183), that is "something done to students" (pg. 183), which inevitably results in a surface approach to learning. On the other hand, "assessment which is the servant rather than the master of the educational process will necessarily be viewed as an integral part of teaching and the practice of improving teaching". Ramsden believes that "a sophisticated theory of teaching leads directly to the proposition that the assessment of students is above all about understanding the processes and outcomes of student learning, and understanding the students who have done the learning. In the application of these understandings, we aim to make both student learning and our teaching better" (Ramsden, 1992).

All workshops were developed to feed directly into and to support the assessment activities. The assessment for ITN336 had evolved over the four years that the teaching team has been involved in the unit. In 2004 students were asked to complete three pieces of assessment focusing on different aspects of reference work. When viewed together the assessment items help the student to develop both a strategic and an operational understanding of reference services. A brief outline of each assessment piece is provided in Table 1. 
Table 1: ITN336 Assessment Items Semester 12004

\begin{tabular}{|l|}
\hline Assessment Item \\
\hline Assessment 1: Reflective Discussion \\
To Be Conducted: Individually \\
Weighting: $20 \%$ \\
Summary: Students are asked to write a reflective discussion on their experience of the Workplace \\
Skills and the Information Professional workshop they are required to attend in Week 4 of semester. \\
Marked By: Gillian Hallam \\
\hline Assessment 2: Reference Service Review \\
To Be Conducted: Groups of 4 \\
Weighting: $60 \%$ \\
Summary: Students are required in teams to review and evaluate an existing Reference and Informa- \\
tion Service of their own choosing. A 7000 written report is to be completed and submitted in hard \\
copy. \\
Marked By: Helen Partridge (Interim Report) and Gillian Hallam (Final Report) \\
\hline Assignment 3: Reference Tool Evaluation - Poster \\
To Be Conducted: Individually \\
Weighting: $20 \%$ \\
Summary: Each student will individually select and evaluate 1 ready reference tool producing a pro- \\
fessional poster that they will present at an industry event. \\
Marked By: Helen Partridge
\end{tabular}

In 1998 Wilson and Martin suggested that team teachers must be "committed to the process of continuous improvement and be willing to spend additional time in planning future lesions, in reflecting on and improving completed ones" (pg. 8). Throughout the 13 week semester, the teaching team would set aside time on a regular basis to critically reflect upon the teaching and learning within the unit. Drawing on the seminal work of Donald Schön (1983), Harris and Harvey refer to this process as reflection-in-action, and suggest it is a "way of constructing new knowledge by critiquing an experience, constructing a new way of understanding it, experimenting with a new response in the future, and further refining this new approach" (pg. 31). They also observe that "if the co-teachers do not share an interest in learning from each other, there will be a limit to the possibilities that can emerge from the teaming experience" (pg. 31). To this end the planning and management of the team teaching in the unit is seen by both team teachers as an integral tool in their own professional development as teachers of merit. To assist in this process of reflection-in-action, a 'team teaching lesson plan' template (Figure 2) was created that would not only clearly articulate the learning objectives and learning activities along with the resource requirements for each workshop, but also provide the opportunity for each member of the team to make notes on areas of further improvement and areas done well.

As part of the reflective process, the teaching team also submitted the ITN336 learning and teaching resources in their entirety to a peer review process which was being piloted by three universities in the region, QUT, University of Queensland and Griffith University. The feedback from the peer review panel was insightful, with the materials being described as meritorious, innovative, challenging and engaging, achieving an overall ranking of Commendable. The reviewers' constructive comments will be used to enhance the teaching and learning approaches in future offerings of the unit. 


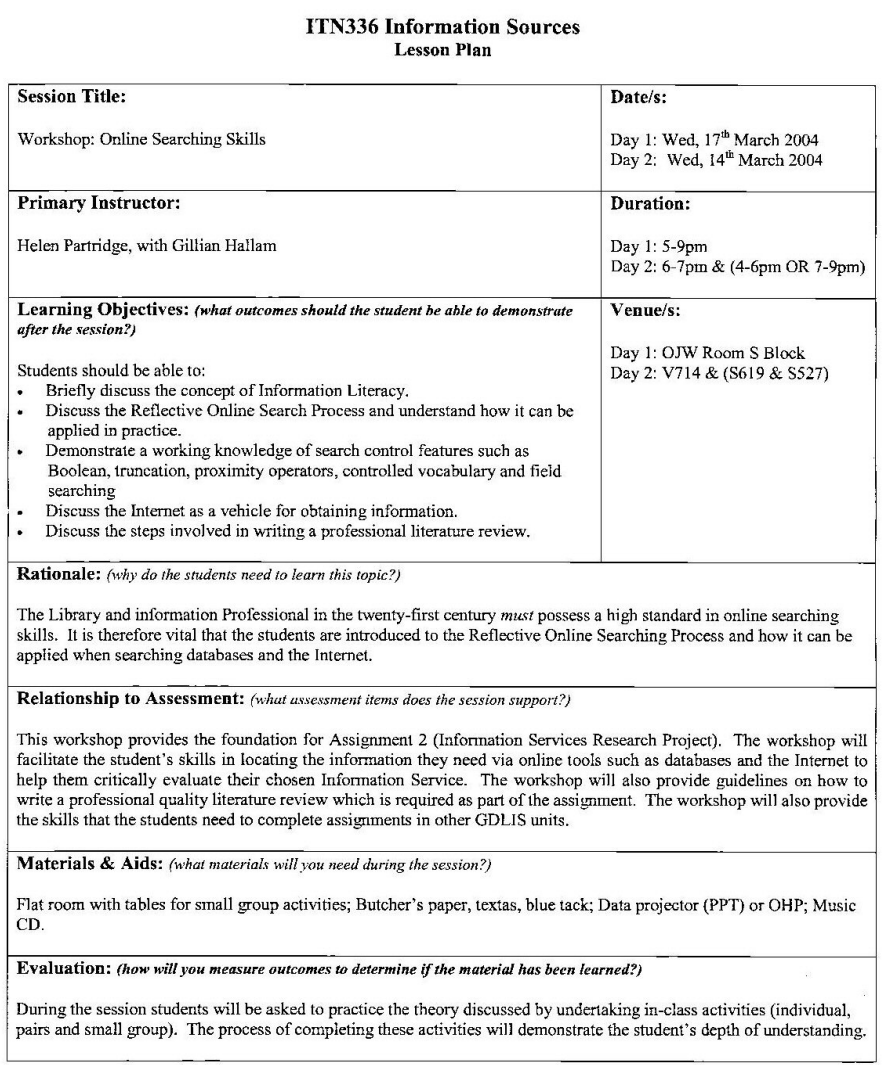

Figure 2: ITN336 Sample Team Teaching Lesson Plan

\section{Students' Perceptions of Team Teaching in ITN336}

Student feedback on the team teaching process in the unit was obtained by self-administered surveys in Week 12 of semester. The survey was designed to explore student perceptions and experiences of team teaching in ITN336 specifically, and within higher education generally. Quantitative data was obtained by asking students to indicate if they agreed or disagreed with a series of statements about their experiences and preferences regarding team teaching on a 5 point Likert scale $(1=$ Stongly Agree and 5=Strongly Disagree). A number of open questions were included to encourage students to respond freely about their experiences. Students were told that their comments would be completely anonymous and confidential and that their involvement in the survey would not impact upon their results in the unit.

Thirty out of the 52 students enrolled in the unit completed the survey. Ages ranged between 19 and 40 with the majority of participants aged between 19 and 25.16 of the participants were full time students, seven were part time and seven were unknown. The results from the survey suggest that the students view team teaching favourably both in the unit and in higher education. Table 2 provides a summary of the results obtained.

The overall responses ranged from 1.9 to 2.3 (the lower the score, the more strongly the students agreed to the statement). As a score less than 2.5 can be viewed as a positive response, the results suggest that team teaching as a technique to foster student learning has been successful in the unit. The best average response to team teaching (i.e. the response where students agreed the most) was in relation to the two questions about the students' overall satisfaction of team teaching in the unit and whether team teaching is a great idea. An average rating of 1.9 was obtained for 
Table 2: Summary of survey results $(n=30)$

\begin{tabular}{|l|c|}
\hline & $\begin{array}{c}\text { Mean Rat- } \\
\text { ing }\end{array}$ \\
\hline (1= Agree Very Much, 3= Not Sure, 5=Disagree Very Much) & 1.9 \\
\hline I think that team teaching is a great idea & 2.3 \\
\hline Team teaching has increased flexibility in my studies within ITN336 & 2.2 \\
\hline Team teaching has facilitated my studies within ITN336 & 2.2 \\
\hline Team teaching has helped me to understand the unit's content & 2.1 \\
\hline Team teaching has improved the teaching and learning value of ITN336 & 2.0 \\
\hline I liked the team teaching strategy used in ITN336 & 1.9 \\
\hline Overall I was satisfied with my experience of team teaching in ITN336 & 2.3 \\
\hline I believe more units at QUT should be taught using team teaching & \\
\hline
\end{tabular}

both points. Students also indicated that they "liked the team teaching strategy used in the unit" (2.0) and that team teaching "improved the teaching and learning value of the unit" (2.1), "facilitated my studies in the unit" (2.2) and helped in "understanding the units content" (2.2). Comments from the students in support of these points included:

"I think this subject is particularly good for group teaching. I would like to attend other courses/subjects using this method of teaching, as I feel I get more out of the lectures than if it's done by a single lecturer".

When asked to identify and discuss which features of the unit's team teaching they liked best, the students identified the following: having access to two different perspectives on the unit content; the interplay between the teachers and their different teaching styles; greater flexibility in obtaining support and asking questions; and the enthusiasm generated by the teaching approach.

Student comments in support of these points include:

"we get a broader view of each topic and you balance each other well. There are twice as many people to run screaming to when there are problems"

"it was fun...there's a more relaxed atmosphere in 336 classes then in the others. At the same time they're much livelier classes. You were able to reinforce each others' teaching and fill in any gaps for the other"

"if one of you forgets something or has trouble explaining something, the other is on hand to help. It made it more enjoyable, learning is easier in that sort of environment".

One other area that was also highlighted but which does not relate directly to the team teaching strategy was the use of workshops instead of lectures. Several students commented that they enjoyed the "flexible time for classes", the "variety in the lectures - especially the 4 hour blocks"; the "workshops were really well planned and organized - helped with all areas in the unit".

When asked to identify what they liked least about team teaching the students identified the following: uncertainty as to who to speak with first regarding a question or problem; inconsistency in instructions and information provided by the different teachers; and being assessed by two lecturers. Therefore, whilst in general students indicated a favourable response to team teaching, it is interesting to note that there were a small number of students in the unit who viewed team teaching in a less than positive light. 
Comments received included:

"I would have rather had two similar classes it would be easier to keep track of things"

"seems like I was in two classes at once"

"[I didn't like having to keep] track of who said what and where they were coming from"

"team teaching in ITN336 could have been better if the separation was by weeks not hours for who was teaching i.e. one teacher for one month, then the other etc".

"I felt that the person who taught me the most in this course was myself. I learned through my own study and experience but not much class work";

These comments suggest that several students in the unit were uncomfortable by the integrated team teaching approach and would have preferred a more traditional model of one teacher to many students, or a serial model of team teaching. It also suggests that the students do not immediately appreciate or understand the rationale behind team teaching and have a somewhat naïve view of the team teaching approach as simply being two teachers in the class room at the same time. In retrospect, a formal introduction to team teaching and how and why it was being used within the unit would have been beneficial in the first week of semester. The session would give the students an opportunity to ask questions about the teaching strategy and to raise any concerns they may have and would enable the teaching team to gauge current student perceptions on the teaching strategy. This strategy will be employed in future offerings of the unit.

Just over one quarter of the students indicated that they had studied a unit at university that incorporated team teaching $(26.67 \%)$. When asked if they enjoyed this experience mixed reactions were noted. Comments included:

"can't see much of a difference as only 1 person can speak at one time"

"consistency was a problem"

"I think we got more professional subject knowledge"

"gave scope for different ways of [explaining]".

Nevertheless, many students were very supportive of the idea of team teaching becoming a core learning strategy with the following comments:

"this is a better approach than teaching by ones self as it (the subject) comes across more clearly as the teachers are more enthusiastic then teaching as an individual"

"needs to be done more - increases interest".

When asked if other units at QUT should engage a team teaching strategy students responded favourably but conditionally. Students indicated that whilst team teaching was successful in ITN336 and contributed to their learning, there was concern that not all the learning approach would be appropriate for all units or handled successfully by all lecturers. Comments included:

"depends on the motivation of the teaching team"

"depends how well the people work together - shows in lectures"

"if the teachers can do so effectively"

"it was delivered well in 336 but I could imagine other lecturers may not suit it as much".

The comments clearly showed the importance of relationship and rapport that is developed between the team teachers, and how aware students are when this relationship is not working. 


\section{Discussion}

When team teaching arrangements are enhanced by complementary teaching styles, it can result in benefits such as those recognised by Bradshaw and Hinton (2000): "It was felt that team teaching would allow them to add spice to the course content, model appropriate communication skills and add more enjoyment to their teaching commitment. Team teaching also offered some added attractive practical benefits: livelier and less formal classroom atmosphere, a cooperative learning environment as modelled by the lecturers; decreased workload and decreased workload stress." (para. 8). The team teaching context stimulates the willingness to try and test new strategies, to mutually reflect on and evaluate the impact on learning and to then further refine these to develop a path of continuing improvement. Positive outcomes can then easily be adapted for other units with little or no risk.

Laurillard (2002, p.86) discusses the pedagogical effectiveness of learning and teaching as an iterative dialogue... which must be discursive, adaptive, interactive and reflective. She refers to this process as a Conversational Framework, echoing ideas promulgated by a number of other authors, with Pask (1976) formalising the concept of learning as a conversation and Ramsden who stated that teaching is a sort of conversation (1992, p.168). Laurillard notes, of course, that in Ancient Greece, the Socratic dialogue played a central role as a discursive teaching strategy. Team teaching can provide the opportunity for the academic staff to open the conversation and to allow the natural personal interaction of a conversation to stimulate contributions from the students.

There are further opportunities for the teaching team to be regarded as models, with the integrated aspects of their lives - simultaneously being teachers and learners, each with their own rich academic, professional and personal lives. As critical reflection is an important dimension of the teaching and learning process, it is valuable to seek feedback on the learning activities, either through informal discussions with students about their experience in the units, through group discussions or questionnaires, or through the formal university evaluation process. The feedback from students may validate the approaches adopted in teaching practice, to enable teachers to build on the strengths, or it may highlight areas of concern that require further examination.

From the teachers' perspective, team teaching was an extremely rewarding experience and offered a wonderful means of introducing new energy into the unit. However, it also posed one significant challenge. In 1995 Davis suggested that "one persistent problem in the support of team teaching is determining the 'teaching load' of the faculty involved in team taught course" (pg. 142). Davis concludes "team taught courses often become a problem for those who do the counting" (pg. 142). The Faculty of Information Technology at QUT is no exception. One of the major problems faced in the four years in team teaching ITN336 is having the workload of the teaching team equitably acknowledged. Faculty administration assumes that team teaching means that the teaching load of the unit is divided evenly between the teachers. In the case of ITN336, this equation means that the 'teaching load' is simply halved between the two teachers. The reality of practice in this unit is quite different. Team teaching is not simply a technique that can be applied to divide the labour within a unit, rather it is a creative and thoughtful mechanism for fostering a dynamic student-centred learning environment. Each member of the teaching team is intimately involved in the planning, design, management and delivery of the learning process.

However, while the university and Faculty apparent pay lip service to the need for "innovative and experiential teaching programs" (QUT, 2004a, pg. 4) in order to provide "one of the best learning environments in Australia" (QUT, 2003, pg. ii), those who are involved in successful team teaching strategies are fully aware of the rift that exists within the organisational culture. It is important that all stakeholders understand the potential value of collaborative teaching and learning activities. Inherently it is not only a question of convincing the administrators of the 
long-term value of maximising quality to develop a collaborative learning community, but also to convince colleagues to take a critical look at their traditional teaching practice to consider the quality of learning that can be achieved through "the richness of the learning community, the multiple perspectives and voices, the integrative experience they are challenged to experience" (McDaniel \& Colarulli, 1997). Open discussion with students, as key stakeholders, is essential to support them as learners, so they understand the role team teaching can play in their education.

\section{Research Limitations}

This research is limited by its reliance on a single case study. Williamson (2002) suggests that "case study research is a useful means of investigating phenomena in their natural setting" (p. 121), but a single case design, such as the one presented here, is limited by the inherent "difficulties in generalising research results" (Williamson, 2002, p. 121). Despite this problem the case study research presented in the current paper provides valuable, preliminary insight into the role and application of team teaching in higher education with the QUT Faculty of Information Technology. Further case studies on team teaching will be added to the data pool as they arise.

\section{Conclusion}

In 2004 the Graduate Diploma in Library and Information Studies will convert to a Master in Information Management (MIM). In practical terms this will result in the course moving from 8 to 12 units with new units being developed and old units being reworked and refined. This revitalisation of the curriculum provides an ideal opportunity for team teaching to become a core feature of the teaching and learning approaches within the course. Within LIS education in the Faculty of Information Technology at QUT, team teaching has already established a "community of practice" where discussions on scholarly teaching and the scholarship of teaching play an increasingly important role for academic staff and students alike.

It is believed that a collaborative working environment, supported by shared teaching philosophies and a strong professional and personal relationship, can be regarded as a valuable representation of the five guidelines for effective teaching collaboration presented by Bennett, Ishler and O'Loughlin (1992): the presence of a genuinely equal relationship; the equal importance of differing knowledge bases; the mutual commitment to engaging in ongoing dialogue and enquiry; the readiness to experience each other's reality in a mutually supportive environment; and the open discussion of any issues and problems that arise. While this ensures a high level of professional satisfaction, as a result of the challenges presented, the risks taken and the ongoing opportunity for continuous improvement, the ultimate winners are the students.

\section{References}

Bakken, L, Clark, F. L, \& Thompson, J. (1998). Collaborative teaching: many joys, some surprises, and a few worms. College Teaching, 46 (4), 154 -157.

Bennett, R. V., Ishler, M. F. \& O'Loughlin, M. (1992). Effective collaboration in teacher education. Action in Teacher Education, 14 (1), 52-6.

Bowden, J. \& Marton, F. (1998). The university of learning: Beyond quality and competence in higher education. London: Kogan Page.

Bradshaw, J. \& Hinton, L. (2000). Team teaching using interactive videoconferencing - virtual 'chaos'. Teaching and Educational Development Institute (TEDI) Conference. Retrieved November 28, 2004, from http://www.tedi.uq.edu.au/confernces/teach conference00/papers/breadshaw-hinton.htm

Davis, J, R. (1995). Interdisciplinary courses and team teaching: New arrangements for learning. American Council of Education. Phoenix, AZ: ORYX Press. 
Eisen, M. \& Tisdell, E. J. (2000). Team teaching and learning in adult education. San Francisco: JosseyBass.

Eisen, M.J. \& Tisdell, E.J. (2002). Team teaching: the learning side of the teaching-learning equation. Essays on Teaching Excellence, 2002-03, 14. Retrieved December 13, 2004, from http://www1.umn.edu/ohr/teachlearn/essays/vol 14/team.html

George, M.A. \& Davis-Wiley, P. (2000). Team teaching a graduate course: Case study: A clinical research course. College Teaching, 38 (2), 75-80.

Harris, C. \& Harvey, A, N. C. (2000). Team teaching in adult higher education classrooms: Towards collaborative knowledge construction. In M.-J. Eisen \& E. J. Isdell (Eds), Team teaching and learning in adult education. San Francisco: Jossey-Bass.

Hinton, S. \& Downing, J. E. (1998). Team teaching a college core foundations course: Instructors' and students' assessments. Paper presented at the Annual Meeting of the Mid-South Educational Research Association. New Orleans, LA, USA. November 4-6, 1998.

Jonassen, D. H. (1991). Objectivism versus constructivism: Do we need a new philosophical paradigm? Educational Technology Research and Development, 39 (3), 5-14.

Laurillars, D. (2002). Rethinking university teaching: A conversational framework for the effective use of learning technologies $\left(2^{\text {nd }} \mathrm{ed}\right)$. London: Routledge Falmer.

Letterman, M. R. \& Dugan, K. B. (2004). Team teaching a cross disciplinary honors course: Preparation and development. College Teaching, 52 (2), 76-79.

Luca, J., Oliver, R., Omari, A., \& Dunbar, A. (2001). Designing an on-line learning environment to support the development of generic skills: A case study. In N. Smythe (Ed.), E-Xplore 2001: A face-to-face odyssey. Proceedings from the Apple University Consortium Conference, September 23-26 2001. Townsville, Australia. Retrieved November 28, 2004, http://auc.uow.edu.au/conf/conf01/downloads/AUC2001_Luca.pdf

McDaniel, E. \& Colarulli, G, C. (1997). Collaborative teaching in the face of productivity concerns: The dispersed team model. Innovative Higher Education, 22 (1), 19-36.

McKee, S. J. \& Day, A. L. (1992). The social studies methods course: A collaborative approach. Social Education, 56 (3), 183-184.

Pask, G. (1976). Conversational techniques in the study and practice of education. British Journal of Educational Psychology, 46, 12-25.

Queensland University of Technology (QUT). (2003). QUT Blueprint. Retrieved November 28, 2004, https://qut.edu.au/frp/perf/qut blueprint.pdf

Queensland University of Technology (QUT). (2004a). QUT Learning and Teaching Plan 2005-2010. Manual of Policies and Procedures. Policy C/1.2. Retrieved November 28, 2004, http://www.qut.edu.au/admin/mopp/C/C_01_02.html

Queensland University of Technology (QUT). (2004b). QUT Teaching Capabilities Framework. Manual of Policies and Procedures. Policy C/7.8. Available [Online] http://www.qut.edu.au/admin/mopp/C/C 07 08.html

Ramsden, P. (1992). Learning to teach in higher education. London: Routledge.

Robinson, B. \& Schaible, R. M. (1995). Collaborative teaching. College Teaching, 43 (2), 57-39.

Schön, D.A. (1983). The reflective practitioner: How professionals think in action. New York: Basic Books.

Speer, T. \& Ryan, B. (1998). Collaborative teaching in the de-centered classroom. Teaching English in the Two Year College, 26 (1), 39-49.

Vogler, K, \& Long, E. (2003).Team teaching two sections of the same undergraduate course: A case study. College Teaching, 51 (4), 122-126. 
Watkins, K. \& Cafarella, R. (1999). Team teaching: Face-to-face and online. Presentation given at the Commission of Professors of Adult Education meeting. San Antonio, TX.

Williamson, K. (2002).Research methods for students, academics and professionals: Information management and systems. $2^{\text {nd }}$ ed. NSW: Centre for Information Studies, Charles Sturt University.

Wilson, V.A. \& Martin, K, M. (1998). Practicing what we preach: Team teaching at the college level. Paper presented at the Annual Meeting of the Association of Teacher Educators. Dallas, TX. February 13-17 1998.

\section{Biographies}

Helen Partridge is a Lecturer in the Faculty of Information Technology. She teaches in the areas of information resources, reference and information services and in-

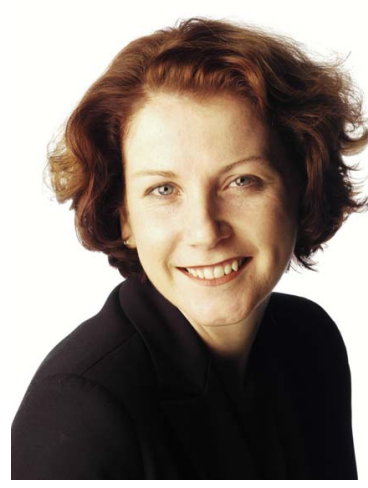
formation literacy. Helen has received several teaching and learning awards including a 2004 QUT Vice Chancellors Distinguished Teaching Award, the 2004 Faculty of Information Technology Dean's Award for Teaching Excellence (with Gillian Hallam for team teaching), the 2004 OLT Compassionate Pioneer Award and the 2003 Faculty of Information Technology Award for Teaching Scholarship (with Gillian Hallam for a jointly written paper). Prior to joining QUT, Helen worked as a library and information professional in both public and special libraries. Helen is a member of the Higher Education Research and Development Society of Australasia (ALISE) and the Association for Library and Information Science Education (ALISE).

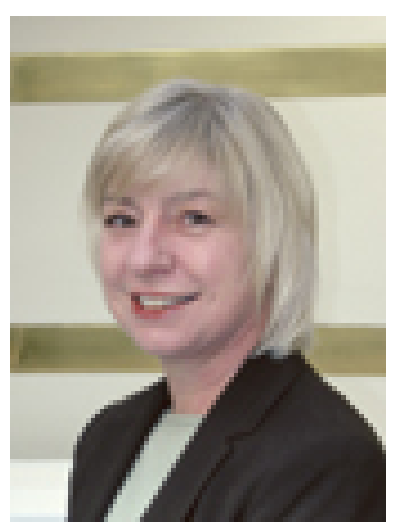

Gillian Hallam is Senior Lecturer in the School of Information Systems at the Queensland University of Technology, coordinating the library and information management courses. She teaches in the areas of information organisation, reference and information services, collection and access management and professional practice. In 2004, Gillian has the additional responsibilities of QUT Teaching Fellow, a role that has involved a cross-faculty community of practice to develop teaching at QUT.

Gillian has published widely in the area of teaching and learning research and has won a number of Faculty teaching awards, including the 2004 Dean's Excellence in Teaching Award (with Helen Partridge, for team teaching), the 2003 Teaching Scholarship Award (with Helen Partridge for a jointly written paper) and the 2002 Director, Teaching \& Learning Innovation in Teaching Award. She has a deep interest in professional development, mentoring and continuing education for information professionals. Prior to joining QUT, she worked as a librarian in the corporate sector, managing business and legal information. In April 2004 she was elected to the position of Vice president (president-elect) of the Australian Library \& Information Association (ALIA) and currently chairs ALIA's Education Reference Group. Gillian is also a member of the Chartered Institute of Library and Information Professionals (CILIP), Special Libraries Association and the Higher Education Research \& Development Society of Australasia (HERDSA). 